\title{
Audit Committee, Effectiveness, Bankruptcy Prediction, and Solvency Level Affect Audit Delay
}

\author{
Bramantio Adi Nugroho', Suripto², Effriyanti ${ }^{3}$ \\ 1,2,3 Universitas Pamulang, Indonesia \\ Email: bramantioadinugroho99@gmail.com
}

\begin{abstract}
This study is to gather empirical evidence on the effectiveness of the Audit Committee, bankruptcy forecasts and audit delay solvency. Various manufacturing industries listed on the Indonesian Börse in 2015-2019 were among the population in this study. A selection from 11 companies with 55 observational data was obtained by using the purposeful sampling technique. Testing of hypotheses and the analyzes is conducted using Eviews10 for the regression of panel data. The findings showed that the efficacy of the audit committee has no significant impact on audit delays, that bankruptcy predictions have a significant impact on the audit delay and that audit delays have a significant impact on the level of solvency.
\end{abstract}

Keywords: Audit Committee Effectiveness, Bankruptcy Prediction, Solvency Level, Audit Delay.

\section{A. INTRODUCTION}

The increasing number of companies in Indonesia going public indicates that the business world in that country is experiencing development. This increase has led to competition among go public companies. They are competing to get funding from investors to continue to exist in today's competitive business world. Companies have to work harder, faster and more accurately to present information about their financial statements in such a competition. In order to take decision on the activities of their investment, the company's financial reports are expected to provide investors with relevant information.

Annual reporting financially provides an important source of information for shareholders and the public on the company's performance and prospects as a basis for investment decision making. The financial statements must contain relevant and reliable information. This is said if the information is quickly obtained. The timeliness in which financial statements are prepared and submitted may affect the value of the information in these financial statements.

In 2020 there is a gap audit delay phenomenon. According to the IDX Assessment Division Team data, 80 companies did not submit their 2019 Annual Report on time (Market.Bisnis.com, 2020). Thus, the issuer that violates the Exchange Rules will be subject to sanctions following Rule Number I-H concerning Sanctions. Based on the regulations of the Indonesia Stock Exchange (IDX), the sanctions that will be given to companies that are late in submitting annual reports include: 1) Written warning I for late submission of financial reports until the end of the 
following month as of the deadline for submitting financial reports; 2) Given a written warning II and a fine of Rp. 10,000,000,- if starting at the beginning of the 2nd month until the listed company still fails to fulfil the obligation to submit financial statements; 3) IDX will give a written warning III and an additional fine of Rp. 30 million if in the 3rd month after the deadline for submission of financial statements, the issuer does not fulfil the obligation to submit financial reports and 4) The last one is suspension if, in the 4th month, the issuer is still absent from its obligations. In some cases, the IDX has even provided fines of up to 150 million if the company wants to stop the suspension.

Following the signal theory, late delivery of company financial reports is indirectly a lousy signal for investors. Investors will consider delays in financial reporting as a bad sign for the company's health so that it will harm market reactions that impact the increase or decrease in the company's stock price. Even though the Indonesian Stock Exchange authorities have imposed sanctions in warning letters or fines to suspension, many companies are still found to be late in submitting annual reports to the Indonesian Stock Exchange every year.

The cause of the audit delay of a company is considered to be several factors. The factors contributing to this are the effectiveness of the audit committee, bankruptcy forecasts and solvency levels. The audit committee is a committee formed by the commissioners' board for the exercise of their duties and duties. The audit committee shall provide opinions on reports and/or matters which have been submitted to the commissioners by the board of directors, identify issues which are necessary for the attention of commissioners and carry out commissioners' duties, for instance, to review the financial information issued by the company, such as financ. The audit committee is responsible for Provisions and other financial details (Bapepam President's Decree Kep Title 2004/29/03). Projections and other financial details. The solvency level is the second factor which is expected to affect audit delay. The results of the Prasilya and Fadjrih (2015) research show that solvency has an impact on the delay of auditing. Due to the size of the company's debt the effect of solvency upon the check delay causes the company debt review to be examined and reported for longer.

Another factor that is thought to affect audit delay in bankruptcy prediction. Economic pain or financial difficulties are considered bad news for the company. To avoid poor quality financial reports, companies often try to improve them. Efforts to improve financial statements require time, so that it will cause audit delay for the company.

Apart from the gap phenomenon, as previously described, this research also found a research gap. The research gap in this study includes differences in research results regarding the variable prediction of bankruptcy and the solvency of audit delay. According to Ratnasari (2016), bankruptcy prediction affects audit delay. The results of Ratna's research contradict the results of Sofiana research (2018). Predictions of bankruptcy and financial distress, according to Sofia, do not affect the 
delay of audit.

Whilst Apriyana (2017) and Debbianita (2017) have discovered the gaps in audit delay in the solvency variable research, the degree of solvency in Apriyana (2017) influences the delay of audit, the results of Debbianita (2017) research indicate that solvency does not impact audit delays. On the basis of the gap and phenomena in research gap described in the background of this study, research on the effectiveness of the Audit Committee, bankruptcy prediction and the delays in audit is necessary.

\section{B. LITERATURE REVIEW}

\section{Agency Theory}

Rohyati and Suripto (2021) stated that the theory of the agency relates to contractual relations between the two parties, the principal and the agent, where the agent has been named by the owner or the investor and administered on behalf of the owner by the owner or by the investor. The theory of the agency concerns the agent. Management authorities shall authorize management to decide on the company's operations. Management of corporate resources is the main responsibility. Management is required to optimize resources for the well-being of owners in the short term and over the long term.

As an officer, management is responsible for the daily operation of the company in the decision making process based on information from management. Accordingly agents have more information than owners. This information gap is often referred to as information asymmetry. Asymmetry of information and conflicts of interest between agents and agents encourage agents to provide false information to the agents (Suripto, 2020).

This information asymmetry raises 2 problems because the principal has difficulties in monitoring and monitoring agent actions. The problem with Jensen and Meckling (1976) is (1) a moral hazard that is when the agent is not doing the things that are agreed on in a work contract and (2) an adverse choice that the agent's principal is unable to understand whether or not a decision on the basis of the information that he has obtained is or is obtained negligently.

Suripto (2020) says the company will have problems with the agency if ownership and management of the company are performed separately. Managers within an enterprise that is responsible for the management are empowered to manage the company management and decide on behalf of the owners. The manager is not acting in the interests of the owner with this authority because of a conflict of interest.

The Agency's theory is that the agent and the agent are separated and therefore the potential conflict may affect the company's financial circumstances. So we need a control mechanism that can harmonize the differences between the two sides. The corporate governance mechanism creates an additional value for all 
staking parties, thus avoiding conflict between the agent and the principal and reducing the agency's costs (Suripto, 2020).

\section{Signalling Theory}

Brigham and Houston say a signal is a company's action to guide investors on how the company views the future of the company. This sign is in the form of information on what the government has done to fulfill the wishes of the owner. Company data is crucial since it affects investment decisions of non-company parties. The report basically provides information, notes or descriptions, both for their history, present and future survival conditions and how it affects the company. This information is essential for investors and business people.

\section{Compliance Theory}

Compliance follows an order or regulation predetermined. Obedience is expected to be executed by companies or issuers on the stock exchange as soon as reporting is possible. This enables a well-established relationship between the Bourse and the company. The theory of compliance should be applied to existing capital market activities. Indonesia requires that companies report on the annual reports of publishers and public companies Chapter III of Article 7, issuers or public companies, as set out in Article 1, submit their annual reports to the Finance Service Authority at the latest 4 months after the end of their report, which is regulated under Financial Service Authority No. 29/POJK.04/2016 Timely reporting is essential to comply with the financial statements information principles of disclosure.

Based on the description above, companies listed on the Indonesian Bourse (IDX) may be concluded that they are required, promptly and promptly, to submit their financial reports. Compliance theory is used to see the extent to which a company can maintain its relationship with shareholders by reporting financial statements promptly following the provisions of the Financial Services Authority. Compliance theory is closely related to the timeliness of writing because the compliance theory can encourage companies to better comply with applicable regulations. The company will endeavour to submit financial reports promptly so that interested parties can use the information from the financial statements. Timely reporting is the company's obligation.

\section{Audit Delay}

Time differential between fiscal year-end and the date of publication of the audit report is often referred to as the audit report lag. Time to complete audit is as long as the independent auditor needs from December 31st to the date indicated in the report of the independent auditor for completion of its audit work. The time of return is measured in days. It calculates the number of days from the closing date of the financial year of the company minus the date when the audited financial 
statements are issued. The auditing process takes time, causing audit delays, which affect the timeliness of financial reports significantly.

\section{Effectiveness of the Audit Committee}

Audit Committee Effectiveness the Audit Committee has been formed and accountable to the Committee of the Commissioners in order to assist the performance of the functions and the duties of the Board of Commissioners according to a Decree of the Chairman of BAPEPAM-LK Number: KEP-643/BL/2012. The setting up of a National Good Corporate Governance Committee in Indonesia confirms the role of the audit committee. The Audit committee's roles and responsibilities are outlined in the charter of the Audit Committee, generally divided into three main sections: financial reporting, corporate management and risk and control. The existence of an audit committee ensures that financial reporting is transparent, fair to all parties involved, and that information carried out by management is communicated, despite conflict of interest. In order to establish fairness, transparency, accountability and responsibility, the audit committee and independent commissioner are parties that supervise and control it. These four factors increase the quality of financial reports.

\section{Bankruptcy Predictions}

Financial distress is due to a failure to support its products and the failure to promote its financial performance, causing the sales to decline so that the decreasing revenue from the lack of sales permits the company to experience operational losses and net losses during the current year. This is due to its inadequate management and retention in financial stability. Further, due to a decrease in the value of the retained earnings used for making dividend payments, the losses resulting in a lack of capital. There will also be a lack of full equity as a whole. If this continues, the total liabilities of the company may exceed the overall assets it has for one day - the conditions mentioned earlier relate to a financially distressed company. In the end, the company will suffer bankruptcy if the company is unable to get off of the above requirements.

\section{Effect of Audit Committee Effectiveness on Audit Delay}

The agency theory view is that there is a separation between the agent and the principal, which results in the emergence of a potential conflict that can affect the company's financial condition. Thus we need a control mechanism that can align the differences in interests between the two parties. The mechanism of corporate governance provides the appropriate mechanism for adding value to all stakeholders so that there is no conflict between the agent and the principal, thereby reducing agency costs.

Agency theory arises because the principal and agent have a conflict of interest that benefits each other. The problems with the agency arise from the 
asymmetry of information, where agents have more information than the principle. Corporate governance mechanisms can solve Agency problems that provide additional value to these stakeholders. The establishment of an audit committee is one of the corporate governance mechanisms.

In order for an audit committee to be able to exercise its functions correctly, the competence of the audit committee is essential. The audit committee, chaired by an accounting expert, will improve the performance of the audit committee. Because it is assumed that the role of Chairman of the Audit Committee is ineffective without sufficient accounting knowledge (Sitorus, 2012).

The better its function is, the shorter the time it takes to report its financial statements, says Atmojo and Darsono (2017). If the auditing committee plays a major part, the lower the financial statements' audit findings will shorten the execution of the audit. Short-term audit completion will allow the Financial Services Authority to submit financial reports more quickly. The efficiency of the audit committee in his research has affected the delay in audit. The hypothesis in this study is as follows, based on this description: $\mathrm{H}_{1}$ : It is suspected that the effectiveness of the Audit Committee affects the Audit Delay.

\section{Effect of Bankruptcy Predictions on Audit Delay}

Based on Signal Theory, financial distress or financial difficulties are considered wrong signals or news for the company. To avoid poor quality financial reports, companies often try to improve them. Efforts to improve financial statements require time, so that it will cause audit delay for the company. Companies that are predicted to go bankrupt tend to experience delays in financial reporting.

If the company is predicted to go bankrupt, the auditors need a longer time in the audit process. Auditors need additional data required to produce opinions following the conditions of the company. When the company is predicted to go bankrupt, there will be delays in financial reporting because auditors need more time in the audit process. Also, auditors need additional data required to produce opinions following the company's conditions (Setyahadi, 2012). The longer process of auditing makes the company's financial reporting slow. The research of Ratnasari (2016) shows that companies expected to go into bankruptcy are less likely than companies expected to be in bankruptcy to submit their financial statements. Bad news (bad news) also are companies expected to go bankrupt, so companies tend not to report on time under this condition. The hypothesis in this study is as follows, based on this description: $\mathrm{H}_{2}$ : It is suspected that the Prediction of Bankruptcy affects Audit Delay.

\section{Effect of Solvency Level on Audit Delay}

Solvency is the ability of the company to pay off its assets for all of its liabilities (both long- and short-term). The debt-to-equity ratio in this study is the 
basis (DER). The high debt rate also increases the financial risk of a company, Carslaw and Caplan (1991) stated. Companies with poor economic conditions therefore tend to be able to engage in maladministration and fraud. In the long run, the audit needs to be examined more thoroughly. The completion process of the financial statement is not affected by companies which carry large total debts with numerous debt-holders or companies which have small total debts with small numbers of debt-holders, as the auditor-designate must have provided time within the required time frame to complete the audit. Debts. Debts. Nurahman and Apriyana (2017) also report that audit delay is affected by solvency. The hypothesis in this study is as follows, based on this description: $\mathrm{H}_{3}$ : It is suspected that the level of solvency affects audit delay.

\section{METHOD}

This research is classified by means of secondary data as a source of research data into quantitative analyses. This study has 26 population groups listed at IDX in 2015-2019 in subsector food \& beverage manufacturing firms. A selection of eleven companies with 55 observational data over five years has been used to determine the sample using a purposeful technique sampling.

Table 1 Sample Selection Results

\begin{tabular}{|c|c|c|c|}
\hline No & Sample Criteria & $\begin{array}{c}\text { Who do Not } \\
\text { Meet the Criteria }\end{array}$ & Accumulation \\
\hline 1. & $\begin{array}{l}\text { For the observation period 2015- } \\
2019 \text {, the Food \& Beverages } \\
\text { industry companies listed on the } \\
\text { Indonesian Bourse. }\end{array}$ & - & 26 \\
\hline 2. & $\begin{array}{l}\text { During the } 2015-19 \text { period, the } \\
\text { manufacturers of Food \& beverages } \\
\text { sub-sectors do not publish full } \\
\text { financial reports. }\end{array}$ & (7) & 19 \\
\hline 3. & $\begin{array}{l}\text { Food \& Beverages sub-sector } \\
\text { manufacturing companies that did } \\
\text { not experience losses during the } \\
\text { 2015-2019 observation period. }\end{array}$ & (4) & 15 \\
\hline 4. & $\begin{array}{l}\text { The Rupia as the functioning } \\
\text { currency is used by a food \& } \\
\text { beverage manufacturing subsector, } \\
\text { listed on the Indonesian Bourse. }\end{array}$ & (4) & 11 \\
\hline \multicolumn{3}{|c|}{ The number of sample companies in 5 years } & 55 \\
\hline
\end{tabular}

Source: $w w w . I D X . c o . i d$

The techniques used to collect data in this study are secondary data documentation techniques. The data used is an annual report by manufacturing companies in the food \& drinks sector listed on IDX in 2015-2019. The technique of 
data analysis consists of descriptive statistics, panel data regression model choice, classic testing on hypotheses, (normality, multi-linearity, heteroskedastics, autocorrelationship). The study uses four variables of research which consist of 1 variable dependent and 3 independent variables.

\section{Variable Measurement}

\section{Effectiveness of the Audit Committee}

The audit committee's effectiveness means the audit committee's ability to fulfil its supervisory duties and responsibilities (DeZoort et al., 2002). The audit committee characteristic index score used in this study are:

\section{Composition of the Audit Committee}

The audit committee's composition consists of the audit committee's independence and the audit committee's expertise.

1. Independence of the audit committee

If all members of the audit committee are external parties, the score is 1 . If one or more audit committees are parties in the company, it is given a score of 0 .

2. The expertise of the audit committee

If at least one member of the audit committee has an educational background and experience in accounting or finance, the score is 1 , otherwise 0 .

\section{Authority of the Audit Committee}

The authority of the audit committee is measured by the presence or absence of an audit committee charter. If there is a charter, it will be given a value of 1 , and if there is no charter, it will be given a value of 0 .

\section{Audit Committee Resources}

Audit committee resources are measured by the number of audit committee members. If the number of members of the audit committee is less than 3 people, the score is 0 , and if the number of members of the audit committee is 3 or more, it is given a score of 1 .

\section{The craft of the Audit Committee}

The audit committee is responsible for the number of audit committee meetings. If the members of the Audit Committee meet at least four times a year, then the score is 1 , or 0 . The maximum score is 5. The Audit Committee Index Effectiveness measures the following formula:

Audit Committee Effectiveness Index $=\frac{\text { Total Audit Effectiveness Score }}{5}$ 


\section{Bankruptcy Predictions}

Predictions of bankruptcy show financial difficulties for companies. In other words, the firm cannot meet or bankrupt its obligations (Ratnasari, 2016). Financial difficulties arise from the failure to promote the products that it manages to reduce sales, so that decreased income from lack of sells allows the company to enjoy operating losses and Net Losses for this current year's period of time. The company's financial performance is not stable and stable (Chairunesia et al., 2018). The Springate method was used in this study to measure financial distress by the following formula:

$$
S=1.03 \mathrm{~A}+3.07 \mathrm{~B}+0.66 \mathrm{C}+0.4 \mathrm{D}
$$

Information:

A: Working Capital/total asset

B: Net Profit interest and taxes/total asset

C: Net Profit before taxes/current liabilities

D: Total asset

From the calculation of the Springate model, the values are divided into two categories, namely, if Springate is negative. On the other hand, the company is in a healthy condition; on the other hand, if Springate is positive, then the company is in an unhealthy state or tends to lead to bankruptcy.

\section{Solvency Level}

The solvency ratio is the ratio used to measure the amount of debt financing for the company's assets (Kasmir, 2014). This means that in comparison with its assets, the company has the debt burden. This is used to measure the ability of the company to fulfill its long-term obligations. The percentage used in this study is debt-to-equities (DER). DER can be calculated with the following formula in reference to Debbianita's research (2017):

$$
\text { Debt Equity Ratio }=\frac{\text { Total Liabilities }}{\text { Total Equity }} \times 100
$$

\section{RESULT AND DISCUSSION}

\section{Descriptive Statistical Analysis}

Descriptive statistical analysis is explained using the mean, maximum, and minimum values. The descriptive statistical analysis results in this study indicate that the average company that experiences audit delay is $78.29 \%$. The highest audit delay of $89 \%$ occurred in the company PT. Mayora Indah (MYOR) in 2019, a minimum value of $46 \%$ occurred at PT. Multi Bintang Indonesia (MLBI) in 2018, and the standard deviation value is 8.310352 . 
Table 2 Descriptive Statistical Test

\begin{tabular}{|l|c|c|c|c|}
\hline & Audit Delay & $\begin{array}{c}\text { Effectiveness of } \\
\text { the Audit } \\
\text { Committee }\end{array}$ & $\begin{array}{c}\text { Bankruptcy } \\
\text { Predictions }\end{array}$ & Solvency Level \\
\hline Mean & 78.29091 & 0.854545 & 1.494553 & 0.872732 \\
\hline Median & 79.00000 & 1.000000 & 1.380330 & 0.870090 \\
\hline Maximum & 89.00000 & 1.000000 & 3.625130 & 2.545870 \\
\hline Minimum & 46.00000 & 0.400000 & 0.429410 & 0.163540 \\
\hline Std. Dev. & 8.310352 & 0.197969 & 0.825131 & 0.568977 \\
\hline Observations & 55 & 55 & 55 & 55 \\
\hline
\end{tabular}

Source: Eviews 10.0 output result

\section{Data Panel Regression Selection Model}

Three panel models of data regression can be used to analyze the panel data, i.e. the standard effect (CEM) model, FEM model and random effect model (REM). Three tests, i.e. the Chow Test, the Hausman Test, and the Lagrange Multiplier Test, are the most suitable models used in panel regression analytics.

The result of this study, which is the Chow test, shows the probability of $0.0069<0.05$ for cross-section F. The panel regression model is selected. The Hausman test shows the probability transverse value $0.2551>0.05$, and the LM test shows that the LM value for Breusch-Pagan is $0.0006>0.05$. The Random Effect (REM) model can thus be concluded as the suitable model to be used as a panel regression model.

Table 3 Conclusion Panel Data Regression Model Testing

\begin{tabular}{|c|l|l|c|}
\hline No & \multicolumn{1}{|c|}{ Method } & \multicolumn{1}{|c|}{ Testing } & \multicolumn{1}{c|}{ Result } \\
\hline 1. & Chow test & Common Effect vs Fixed Effect & Fixed Effect \\
\hline 2. & Hausman Test & Random Effect vs Fixed Effect & Random Effect \\
\hline 3. & Lagrange Multiplier Test & $\begin{array}{l}\text { Common Effect vs Random } \\
\text { Effect }\end{array}$ & Random Effect \\
\hline
\end{tabular}

\section{Classic Assumption Test}

Normality test

The normality test aims to test whether the confounding or residual variables have a normal distribution in the regression model. Figure 1 shows that the probability value is $0.095172(0.095172>0.05)$, it can be concluded that the residuals are normally distributed. 


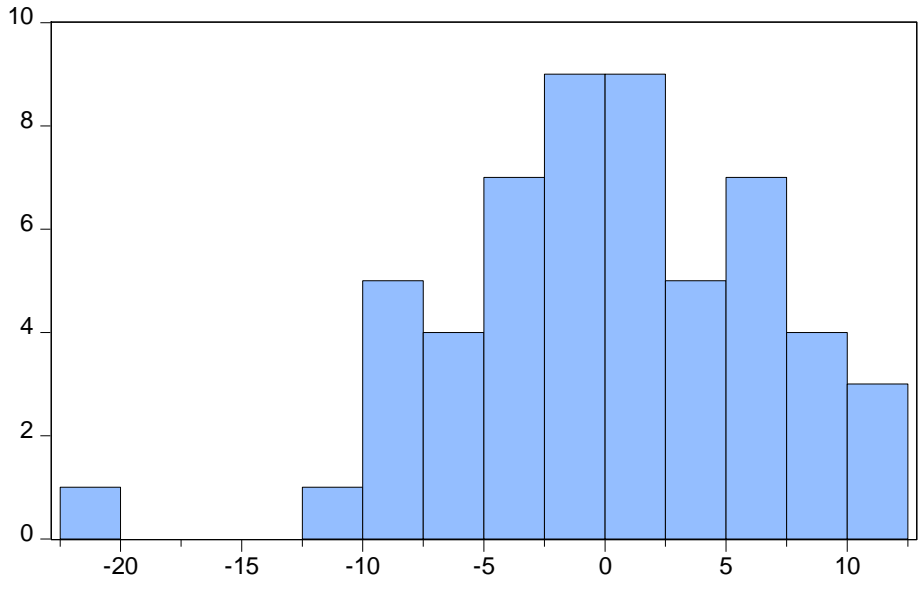

Figure 1 Normality Test
Series: Standardized Residuals

Sample 20152019

Observations 55

Mean $\quad 2.06 \mathrm{e}-14$

Median $\quad 0.103016$

Maximum $\quad 11.89643$

Minimum $\quad-21.47003$

Std. Dev. $\quad 6.365541$

Skewness $\quad-0.550943$

Kurtosis $\quad 3.915729$

Jarque-Bera $\quad 4.704131$

Probability $\quad 0.095172$

Source: Eviews 10.0 Output Result

\section{Multicollinearity Test}

If the relationship between the two independent variables does not exceed 0,80 the regression model is free of multicollinearity problems (Ghozali \& Ratmono, 2017). In this study, researchers used the correlation matrix to test the presence or lack of multicollinearity issues. Tab 4 shows that the correlation between the Effectiveness $\left(X_{1}\right)$ audit committee and the Bankruptcy Predictions $\left(X_{2}\right)$ is -0.022950 . The correlation among the Effectiveness $\left(X_{1}\right)$ audit committee and solvency $\left(X_{3}\right)$ is: 0.040384. There is no correlation in this study that is more than 0.80 between separate variables so it can be concluded that the independent variables are not multicolored.

Table 4 Multicolonierity Test

\begin{tabular}{|c|c|c|c|}
\hline & $\mathrm{X} 1$ & $\mathrm{X} 2$ & $\mathrm{X} 3$ \\
\hline $\mathrm{X} 1$ & 1.000000 & -0.022950 & -0.040384 \\
\hline $\mathrm{X} 2$ & -0.022950 & 1.000000 & -0.074293 \\
\hline $\mathrm{X} 3$ & -0.040384 & -0.074293 & 1.000000 \\
\hline
\end{tabular}

Source: Eviews 10.0 output result

\section{Heteroscedasticity Test}

The heteroscedasticity test takes place if the predictive and residual values have a correlation or pattern of relation. To test in the Glejser test for the presence or absence of problems of heteroscedasticity. The heterozedasticity-free data is declared if the probability value of the independent variable is above 0.05 . Table 5 shows that each individual variable's probability value exceeds 0.05 . This shows that the model has no problem with heteroscedasticity. 
Table 5 Multicolonierity Test

\begin{tabular}{crrrr}
\hline Variable & Coefficient & Std. Error & t-Statistic & Prob. \\
\hline X1 & 4.781752 & 3.041936 & 1.571944 & 0.1221 \\
X2 & 1.604175 & 0.846031 & 1.896118 & 0.0636 \\
X3 & 0.542165 & 1.050141 & 0.516278 & 0.6079 \\
C & -2.046190 & 3.195752 & -0.640284 & 0.5249 \\
\hline
\end{tabular}

Source: Eviews 10.0 output result

\section{Panel Data Regression Analysis}

Based on the previous selection of regression models, the Random Effect model is the most appropriate regression model to be used in this study.

Table 6 Results of Panel Data Regression with Random Effect

\begin{tabular}{crrrr}
\hline Variable & Coefncient & Std. Error & t-Statistic & Prob. \\
\hline$\times 1$ & -5.786502 & 5.157619 & -1.121933 & 0.2671 \\
$\times 2$ & -4.802250 & 1.407554 & -3.411770 & 0.0013 \\
$\times 3$ & -4.787368 & 1.783154 & -2.684775 & 0.0098 \\
C & 94.59105 & 5.400188 & 17.51625 & 0.0000 \\
\hline
\end{tabular}

Source: Eviews 10.0 Output Result

The regression equation from table 4 with the dependent variable enterprise risk management disclosure is as follows: $\mathrm{Y}=\mathbf{9 4 . 5 9 1 0 5}$ - 5.786502 $4.802250-4.787368+e$

\section{Hypothesis testing}

\section{Coefficient of Determination}

Table 6 shows that determination coefficients are 0.261090 (RSquare), and the adjusted determination coefficient is 0.217625 (Adjusted $\mathrm{R}^{2}$ ). This makes it possible to explain 21.7 percent of the variation of the audit delay by variations of individual variables (audit committee effectiveness, bankruptcy predictions, and earnings management). Whereas the other variables $(100 \%-21.7 \%=78.3 \%)$ are explained not in this study by other variables.

Table 6 Determination Coefficient Test

\begin{tabular}{llll}
\hline R-squared & 0.261090 & Mean dependent var & 50.20890 \\
Adjusted R-squared & 0.217625 & SD dependent var & 6.633128 \\
\hline
\end{tabular}

Source: Eviews 10.0 output result

\section{Simultaneous Test (Test Statistic F)}

Table 7 shows that the Fount value obtained is 6.006873 with a significant value of 0.001384 . Meanwhile, to find Ftable with the number of samples $(n)=55$, the number of variables $(\mathrm{k})=4$, and the significant level $=0.05$, then $\mathrm{df} 1=\mathrm{k}-1=4-1=3$ and df2 $=\mathrm{NK}=55-4=51$, obtained the Ftable value of 2.79. So that Fount (6.006873) $>$ Ftable (2.79) with a significant value $0.001384<0.05$ significant level. This shows 
that the audit committee's effectiveness, the prediction of bankruptcy, and the level of solvency simultaneously and significantly influence audit delay.

Table 7 Significant Test Results $\mathbf{t}$

\begin{tabular}{llll}
\hline \hline F-statistic & 6.006873 & Durbin-Watson stat & 1.733642 \\
Prob(F-statistic) & 0.001384 & & \\
\hline
\end{tabular}

Source: Eviews 10.0 output result

\section{Partial Test (t-test)}

The t-test was conducted to determine the effect of each independent variable partially on the dependent variable. If the probability value is less than 0.05 , the proposed hypothesis is accepted, and vice versa if the probability value is more significant than 0.05 , the proposed theory is rejected.

Table 8 Significant Test Results $t$

\begin{tabular}{crrrc}
\hline \hline Variable & Coefficient & Std. Error & t-Statistic & Prob. \\
\hline \hline X1 & -5.786502 & 5.157619 & -1.121933 & 0.2671 \\
X2 & -4.802250 & 1.407554 & -3.411770 & 0.0013 \\
X3 & -4.787368 & 1.783154 & -2.684775 & 0.0098 \\
C & 94.59105 & 5.400188 & 17.51625 & 0.0000 \\
\hline
\end{tabular}

Source: Eviews 10.0 output result

1. The results show that the count value is smaller than the table $(-1.121933<$ $2.00665)$, and the significant matter is greater than $0.05(0.267>0.05)$. Thus it can be concluded that the audit committee effectiveness variable does not affect audit delay.

2. The results show that the $t$-count value is greater than the $t$-table $(-3.411770>$ $2.00665)$, and the significant matter is smaller than $0.05(0.0013<0.05)$. Thus it can be concluded that the bankruptcy prediction variable harms audit delay.

3. The results show that the $t$-count value is greater than the $t$-table $(-2.684775>$ 2.00665), and the significant matter is smaller than $0.05(0.0098<0.05)$. Thus, it can be concluded that the solvency level variable harms audit delay.

\section{E. CONCLUSION}

The following conclusions can be drawn, based on data collected and processed along with the testing of the effectiveness variable of the Audit Committee, the prediction of bankruptcy and the audit delay degree of solvency: (1) No significant impact on the variable effectiveness of the audit committee against the delay of the audit. This does not affect the effectiveness of the audit committee on audit delays as the audit committee has no direct role in the preparation of the audit report. 2) The variable banking forecasting has a significant adverse effect on the audit delay. The audit committee serves as the sole supervisor when preparing the 
independent auditor's report. The predictions of bankruptcy have a significant negative effect in relation to audit delay, since auditors require a longer time to complete audit reports when the company is forecast to be in bankruptcy. The solvency level significantly adversely affects the audit delay. The amount of debt and equity owned by the company can also be interpreted as a compared comparison.

\section{REFERENCES}

1. Alifa, A. R., Sinulingga, N. F., Sibarani, R. O., Waryu, W., \& Suripto, S. (2020). Pengaruh Corporate Social Responsibility, Intensitas Modal dan Koneksi Politik Terhadap Agresivitas Pajak. Proceedings Universitas Pamulang, 1(1), 104-117.

2. Apriana, N. (2017). Pengaruh Profitabilitas, Solvabilitas, Ukuran Perusahaan, dan Ukuran Kap Terhadap Audit Delay Pada Perusahaan Properti dan Real Estate Yang Terdaftar di Bursa Efek Indonesia Periode 2013-2015. Nurnal Nominal Universitas Negeri Yogyakarta, 4(2).

3. Baridwan, Z. (2004). Intermediate Accounting. Yogyakarta: Bpfe.

4. Carslaw, C. A. P. N., \& Kaplan, S. E. (1991). An Examination of Audit Delay: Further Evidence from New Zealand. Accounting and Business Research, 22(85), 2132.

5. Debbianita, V. S. H. \& Ivana. (2017). Pengaruh Profitabilitas, Solvabilitas, dan Aktivitas Persediaan Terhadap Audit Delay Pada Perusahaan Retail Yang Terdaftar di Bursa Efek Indonesia Periode 2014-2015. Jurnal Akuntansi Maranatha, Program Studi Akuntansi, Fakultas Ekonomi, Universitas Kristen Maranatha, 9(2).

6. Dyer, J. C., \& Mchugh, A. J. (1975). The Timeliness of the Australian Annual Report. Journal of Accounting Research, 13(2), 204-219.

7. Horne, J. C. V., \& Jhon, M. W. (2016). Prinsip-Prinsip Manajemen Keuangan. Jakarta: Salemba Empat.

8. Jensen, M., C., \& Meckling, W. (1976). Theory of the Firm: Managerial Behavior, Agency Cost and Ownership Structure. Journal of Finance Economic, 3, 305- 360.

9. Joy, J. (2018). Pengaruh Efektivitas Komite Audit Terhadap Audit Report Lag. Jurnal Ilmiah Mahasiswa FEB, 7(1).

10. Jusup, H. (2001). Dasar-Dasar Akuntansi. Yogyakarta: STIE YKPN.

11. Ratnasari, I. K., \& Ardiati, Y. (2016). Pengaruh Karakteristik Komite Audit, Prediksi Kebangkrutan dan Kepemilikan Publik Terhadap Audit Report Lag. Modus, 28(2), 117-136.

12. Mulyadi. (2002). Auditing, Buku 1. Jakarta: Salemba Empat.

13. Nasution, M., \& Setiawan, D. (2007). Pengaruh Corporate Governance Terhadap Manajemen Laba di Industri Perbankan. Simposium Nasional Akuntansi X, Makassar.

14. Novitasari, A., Mulyani, A. T., A'yun, S. Q., Purwaningsih, T., \& Suripto, S. (2020). Pengaruh Pengungkapan CSR (Corporate Social Responsibility), 
Kebijakan Dividen, Dan Tingkat Inflasi Terhadap Harga Saham. Proceedings Universitas Pamulang, 1(1), 36-41.

15. Pitriani, N., Haryanti, P., Adriansyah, T., \& Suripto, S. (2020). Pengaruh Pendapatan Usaha, Biaya Operasional, dan Volume Penjualan Terhadap Laba Bersih. Proceedings Universitas Pamulang, 1(1), 14-20.

16. Platt, H. D., \& Platt, M. B. (2006). Understanding Differences between Financial Distress and Bankruptcy. Review of Applied Economics, 2(2), 141-157.

17. Prahesti, E., \& Supri. W. U. (2019). Pengaruh Profitabilitas dan Solvabilitas Terhadap Audit Delay Pada Perusahaan Perbankan Yang Terdaftar di Bursa Efek Indonesia (BEI). Forum Ilmiah Pendidikan Akuntansi Progam Studi Pendidikan Akuntansi-Fkip Universitas Pgri Madiun.

18. Putri, A. N. S., Lebata, C. E., Sari, N., Supriadi, R., \& Suripto, S. (2020). Pengaruh Kompetensi, Independensi dan Integritas Terhadap Kualitas Audit. Proceedings Universitas Pamulang, 1(1), 78-88.

19. Rohyati, Y., \& Suripto, S. (2021). Corporate Social Responsibility, Good Corporate Governance, and Management Compensation against Tax Avoidance. Budapest International Research and Critics Institute (Birch-Journal): Humanities and Social Sciences, 4(2), 2612-2625.

20. Sugiyanto, S., Febrianti, F. D., \& Suripto, S. (2020). Good Corporate Governance and Tax Avoidance to Cost of Debt with Growth Opportunities Moderating (Empirical Study on Manufacturing Company and Finance Service Listed In Idx 2015-2019). The Accounting Journal of Binaniaga, 5(2), 123-140.

21. Sugiyono. (2013). Metode Penelitian Bisnis (Pendekatan Kuantitatif, Kualitatif, Dan $R \mathcal{E D})$. Bandung: Alfabeta.

22. Sugiyono. (2017). Statistika Untuk Penelitian. Bandung: Alfabeta.

23. Suripto, S. (2019). Corporate Social Responsibility and Creating Shared Value: A Preliminary Study from Indonesia. International Journal of Contemporary Accounting, 1(1), 23-36.

24. Suripto, S. (2020, February). Pengaruh Pemanfaatan Tax Haven, Withholding Taxes, Dan Ukuran Komite Audit Terhadap Praktik Thin Capitalization. In Proseding Seminar Nasional Akuntansi, 2(1).

25. Suripto, S., \& Sugiyanto, S. (2021). Transparansi Perusahaan Memoderasi Pengaruh Tax Avoidance dan Leverage Terhadap Nilai Perusahaan Manufaktur Di Bursa Efek Indonesia. Proceedings Universitas Pamulang, 1(1).

26. Suripto. (2019). Pengaruh Tarif Pajak, Earning per Share Dan Pertumbuhan Penjualan Terhadap Harga Saham (Studi Empiris Perusahaan Manufaktur Yang Terdaftar di Bursa Efek Indonesia Tahun 2012-2016). 